\title{
Changing Negative Personality Protection to Successful Strategies for Coping with Stress in the Psycholinguistic Aspect
}

\section{Зміна негативного захисту особистості на успішні стратегї̈ опанування стресом у психолінгвістичному аспекті}

\author{
Oleksandra Kohut \\ Ph.D. in Psychology, Assistant Professor of Social Sciences \\ and Humanities, Donetsk Law Institute of the Ministry of Internal \\ Affairs of Ukraine, Kryvyi Rih (Ukraine) \\ ORCID ID: https://orcid.org/0000-0003-0116-2274 \\ E-mail: Aleksandra13-76@ukr.net

\section{Олександра Когут} \\ Кандидат психологічних наук, доцент кафедри соціально-гу- \\ манітарних дисциплін, Донецький юридичний інститут МBC \\ України, м. Кривий Ріг (Україна)
}

\section{ABSTRACT}

The aim of the article. Based on the theoretical analysis of cognitive schemes, scenario matrices of destructive games and their transactions, the author tries to apply his own psychotherapeutic method "Exit from the triangle of S. Karpman".

Methods. Theoretical analysis of psychotherapeutic areas of work with the problem of Victim in psychological science is used. The attention is paid to the causes of the stress problem, in particular, the usual ways of human response to stress: schemes, scenarios, scenario prescriptions, scenario matrices. Research

Address for correspondence, e-mail: kpnu_lab_ps@ukr.net Copyright: (C) Kohut Oleksandra

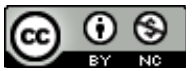


of empirical indicators of efficiency of application of a new method: projective technique of O. S. Romanova and T. I. Sitko "Man in the rain»; stress diagnosis, based on Max Luscher's colour cards; author's method "Diagnosis of stress resistance of the individual»; E. P. Ilyin's method of "Transaction analysis»; method of clinical conversation.

The results of the research. Most people who need to develop stress resistance in the initial stages raise the issue of interdependent relationships with aggressors or victims and apply negative protections, which generally contributes to inadequate responses to stress. Exemption from the internal causes of dependence, from destructive defences and schemes and the transition to a state of voluntary observer gives a person the opportunity to choose ways to react to stress, coping strategies, life scenarios, plan for the future, live your own life. The author carried out a theoretical analysis of the psycholinguistic aspect of personality development. In particular, the communicative behaviour of the individual is studied: communicative-cognitive schemes, transactional script prescriptions and drivers. The study paid special attention to such psychotherapeutic areas as psychoanalytic, Gestalt, cognitive-behavioural, neurolinguistic integrated programming. They provided an opportunity to reveal the essence and content of the psycholinguistic messages of the Victim, the Persecutor and the Saviour.

Conclusion. The results of empirical diagnostics indicate the effectiveness of the method "Exit from the triangle of S. Karpman". Observations and conversations provided an opportunity to state the following: patients achieved the integration of all triangle roles, the level of self-awareness expanded, there was a change of negative programs to successful stress management strategies, the Victim's role was changed to successful stress management strategies. The projective technique "Man in the rain" revealed elements of security and the absence of anxiety; M. Luscher's colour test - the absence of internal conflict and the presence of healthy conditions. More than 100 participants of the training on the development of personality stress resistance were tested in the new method.

Key words: defence mechanisms, S. Karpman's triangle, state of the Victim, state of Tirana, state of the Saviour, state of the Observer, successful coping strategies.

\section{Introduction}

Stress is the cause of many somatic diseases, it worsens the immune system, forms a person's predisposition to infectious

(C) Kohut Oleksandra

DOI (article): https://doi.org/10.32626/2227-6246.2021-51.54-75 
DOI: https://doi.org/10.32626/2227-6246.2021-51 2021. випУСК 51

diseases, some forms of cancer and autoimmune diseases, drug addiction, affects the formation of psychosomatic disorders (Nagolnik, 2015; Selye, 1992), is the cause of emotional burnout at work, maladjustment of personality in society (Kohut, 2021). The causes of stress associated with the maladjustment of a person in society are destructive games (Berne, 1992), frustrations (Dollard, 1939), maladaptive coping strategies (Lazarus, 1970), destructive schemes (Sardarzade, 2019; Yang, 2003), neuroses (Horney, 2019), excessive cognitive dissonance (Festinger, 2018), internal disintegration (Jung, 1997) of the personality. All these reasons are united by one truth: a person who is powerless in the face of the problems of society, feels himself a Victim, resorts to extremes in actions.

Despite a significant number of modern methods of dealing with stressful problems, the stress associated with the psychology of the victim remains poorly researched. For the first time, the psychology of victim began to be investigated by criminologists in the aspect of victimology, which studied victims of criminal behaviour: D. V. Rivman developed a classification of personal characteristics of the victim property (Rivman, 2002), V. A. Tulyakov proposed a motivational classification of victims (Malkina-Pykh, 2016), A. Plotnikov described a variety of victims of "guilty without guilt» and those who are really guilty, but constantly repeat their actions (Malkina-Pykh, 2016). Victimologists single out Murder Victims, Rape Victims, Torture Victims, Fraud Victims. There are few studies conducted in non-criminal victimology today.

The relevance of the chosen topic has a wide meaning: the scientific and theoretical one covers the theoretical analysis of modern and domestic directions in the study of the communicative behaviour of an individual (pre-verbal and verbal language schemes, script prescriptions, drivers) (Berne, 1992; Goulding, 1997; Kovalyov, 2016; Malkina-Pykh, 2016; Karpman, 2016), as components of the scenario matrix, on the basis of which the self-organization of its life is carried out (Dyakov, 2020). (c) Kohut Oleksandra

DOI (article): https://doi.org/10.32626/2227-6246.2021-51.54-75 
The methodical one reveals modern psychotherapeutic practices of getting out of the Victim script (Aaron T. Beck, 1991; Karpman, 2016; Kohut, 2021). The empirical-methodological one has applied value in dealing with stressful issues. We see the problematic of the study in the search for techniques for replacing negative programs of protection of the Victim with successful coping strategies of the individual.

Psychologists argue that the role of the Winner or Victim of stressful situations is determined by the scenario matrix, the model of world perception (Kucher \& Baksanskyi, 2010). The model of the world of personality is considered by psychologists as an established cognitive scheme (Yang, 2003), life plan of the scenario (Berne, 1992), beliefs (Aaron T. Beck, 1991). Scientists believe that the basis for the formation of a model of the world and a scenario matrix of personality is the relationship of a child with a mother in the early stages of development, as stated in the theory of attachment by J. Bowlby and M. Ainsworth (Malkina-Pykh, 2016). P. Crittenden identified the basic properties of mother that contribute to the formation of positive attachment: emotional acceptance of the child, the mother's responsiveness to the child's states and needs, the constancy, consistency of the mother's behavior, and a high level of subjectivity of communication (Malkina-Pykh, 2016).

This type of attachment provides the child with a positive background of trust in the world. Dangerous attachment is formed in children whose mothers were overly anxious, with ambivalent reactions to the child's actions, disorganized (violent). K. Bartalomew and L. Horowitz proposed models of four types of adult attachment: reliable "I am ok, you are ok»; anxious «I am not ok, you are ok», avoiding-repulsive «I am ok, you are not ok», fearfully avoiding «I am not ok, you are not ok» (Malkina-Pykh, 2016). A person who has incomplete gestalts of childhood is guided by double motives: adult life requires movement towards goals, and internal needs motivate to seek love and protection. Not feeling safe and comfortable

(C) Kohut Oleksandra

DOI (article): https://doi.org/10.32626/2227-6246.2021-51.54-75 
DOI: https://doi.org/10.32626/2227-6246.2021-51

2021. виПуСК 51

in the world, a person who is broken at the beginning of his life feels like a Victim.

The goal of the study is to test a new author's method «Way out of S. Karpman's triangle».

\section{Object of the article}

Considering the above mentioned information, we strive to carry out the analysis of scientific works and psychotherapeutic practices of transformation of the state of the Victim; explore the communicative behaviour of the Victim and the Winner; reveal the essence of the roles of Victim, Persecutor, Rescuer and understand the deep mechanisms of dramatic games. And also we will supplement the psychotherapeutic subject with a new method «Way out of S. Karpman's triangle».

\section{Methods and methodology of the research}

The theoretical and methodological foundations of the research are: A. Adler's concept of neuroses; the theory of frustration - aggression by L. Berkovets, J. Dollar, N. Miller (Berkovets, 1969); E. Berne's theory of transactional analysis (Berne, 1992); theory of information stress V.A. Bodrov; attachment theory by J. Bowlby and M. Ainsworth (Malkina-Pykh, 2016); delineating the personality of $\mathrm{B}$. Weinhold and J. Weinhold; research of coping strategies in neurotics B. D. Karvasarskyi; the concept of integral neuroprogramming by S. V. Kovalev (Kovalyov, 2016), the cognitive theory of stress by R. S. Lazarus (Lazarus, 1970); studies of the psychology of victim behaviour by I. Malkin-Pykh (Malkina-Pykh, 2016) the concept of stress by G. Selye (Selye, 1992); L. Festinger's theory of cognitive dissonance (Festinger, 2018), B. Helinger's constellation method (Helinger 2013), definition of the concept of "victim» in the work of V.E. Khristenko (Khristenko, 2004); psychotherapy of the essence and the "developing role of neurosis» by C. Jung (Jung, 1997), the theory of early maladaptive schemes by J. Yang (Yang, 2003), and others. (c) Kohut Oleksandra

DOI (article): https://doi.org/10.32626/2227-6246.2021-51.54-75 
The following empirical methods were also applied: the projective technique by A.S. Romanova and T.I. Sitko «Man in the Rain"; stress diagnostics using color cards by Max Luscher; author's methodology "Diagnostics of personality stress resistance»; method of «transactional analysis» by E. P. Ilyin; method of clinical conversation; method of O. A. Kohut «Way out of S. Karpman's triangle» .

\section{The discussion results}

Developing the ideas of Eric Berne, his student Stefan B. Karpman showed in 1968 that all the variety of roles that underlie "games that people play can be" reduced to three main ones: Rescuer, Persecutor, and Victim (Karpman, 2016). The scientist developed the psychoanalytic direction of the study of unhealthy interactions between people, which is now called «S. Karpman's dramatic triangle». All three roles are interrelated: the Rescuer helps the Victim tyrannized by the Persecutor. Let's consider their hidden mechanisms and schemes. The persecutors can be aggressors, domineering natures and despotic tyrants. They are characterized by a strategy of «all-out war» according to K. Horney, they are guided by the dominant need to "survive», which prompts them to directly demonstrate power, sadistic inclinations, rivalry, and exploit others (Horney, 2019). Eric Berne described them in transactional analysis as authoritarian parents. A cornered child loses contact with his creative source, the spontaneous manifestation of his own impulses, does not feel «involved" in life. The behavior of the Persecutor, as described in the gestalt of integrated psychotherapy by Irwin and Miriam Polster, is based on a protective mechanism of «fusion» or "confluence», it allows building relationships only according to the established rules of one of the interlocutors. If the rules are violated by another interlocutor, then he / she is considered an enemy. The Victims' psyche has its own defence mechanisms that support unhealthy transactional games - «introjection» helps them maintain unhealthy

(C) Kohut Oleksandra

DOI (article): https://doi.org/10.32626/2227-6246.2021-51.54-75 
DOI: https://doi.org/10.32626/2227-6246.2021-51

relationships with confluent persons, they sacrifices their interests, impulses for life, trying to avoid conflicts.

Diagnostics of neurotic patients in a psychotherapeutic day patient department using Max Luscher's colour cards showed the following: the presence of stress caused by the inability to maintain relationships in the desired state all the time; tries to match his ideal concepts, ignoring reality; desire to independently control their own destiny; stress caused by frustration and fear of further failure; anxiety and impulsivity caused by emotional dissatisfaction; the presence of psychological conflict and distress, which is a source of anxiety. Having studied their stories deeper during the clinical conversation, we came to the conclusion that all these diagnoses are united by the scenario of a tragic triangle.

Aaron Beck, one of the founders of cognitive-behavioural psychotherapy, noted that behind every maladaptive emotion there is a negative belief that prevents a person from perceiving the world more adequately (Aaron T. Beck, 1991). In Victims they are: if I am not at the top, then I am in the pit; if I made a mistake, then I am nothing; it's good to be popular, but it's terrible to be unknown; I cannot live without love, if my loved ones DO NOT love me, then this is terrible; if I don't use every opportunity to get ahead, then I'll have to pay a heavy price; I must be successful in any business; I need to be loved, to be accepted as such, to be admired by everyone and all the time; my value as a person depends on what people think of me; if someone does not agree with me, it means that he does not love me. These beliefs compensate for the true needs and values of a person. The neurotic is NOT aware of the reasons for his anxiety and continues to play games that DO NOT provide him with full emotional satisfaction. A constant source of stress remains UNDETERMINED. Bert Helinger noted that games lead to death, not life (Helinger, 2013).

A neurotic person does not see the real reasons for his acting, at the moment of stress he is forced to change roles, like (c) Kohut Oleksandra

DOI (article): https://doi.org/10.32626/2227-6246.2021-51.54-75 
an actor on stage: now the Victim, then the Persecutor, then the Rescuer. The game can be played by two, for example, in a family or friendly couple; three or more participants, for example, a husband-wife-psychotherapist. Such a game resembles a run in a circle, there are always three main roles, and this is what allows the game to go on forever: Winner, Loser, Filure. It can be recognized by the positions described by E. Berne. The victims may be suicidal; or they may be depressing - consider others better than themselves. The Rescuers consider themselves good and the others bad. The Persecutors take the position of a snob and also consider themselves good and others pagans. Black and white thinking makes it easier for people to orient themselves in relationships with others. But dichotomous positions in a two-dimensional plane do not reflect the essence of human relations and make people unhappy. According to the principle of systems analysis, if they realize that something is repeating in their lives, they have a chance to change their usual roles into more effective ways of interacting with others.

Having become familiar with the patient's communication behaviour, you can determine his scenario. The winner is usually expressed like this: «Now I know how to do it», «Next time I will not miss». The Winner's Scenario is programmed by caring parents. Losers are expressed like this: "If only...», "I would of course...», "Yes, but...». They are often virtuous citizens who harbour destructive scenarios of the intimidated Child. If they get into trouble, they drag everyone around them into it. A script-free person can say, «I did exactly what I wanted».

The neurotic himself is an obstacle encoded in his life script. It is difficult to get rid of it on your own, because each participant receives some benefit from his role. The victims can shift responsibility for their problems onto another people, can revel in self-destruction, a sense of self-pity. The persecutors receive a sense of righteous anger, a sense of their

(C) Kohut Oleksandra

DOI (article): https://doi.org/10.32626/2227-6246.2021-51.54-75 
DOI: https://doi.org/10.32626/2227-6246.2021-51 2021. випуск 51 righteousness, a release of tension, aggression. The Rescuer receive a special, perverse pleasure. They seem to be above this couple, and this fact gives them a sense of superiority over others.

Most of the advices of psychologists on their Internet pages refers to the cognitive aspect of a strong-willed personality. The victims needs to realize that in order to satisfy their own desires, people need only themselves; they must learn to take responsibility for themselves, to act without looking back; do not make excuses. The persecutors should stop blaming other people and circumstances for their problems; understand that no one is obliged to conform to their ideas about what is right and wrong; learn to accept others as they are, without changing them, to resolve misunderstandings peacefully, without aggression and anger; stop being affirmed at the expense of those who are weaker. For Rescuers, there are such tips: do not help if no one asks; not to think that you know better how others should live; do not promise rashly; DO NOT expect gratitude and praise; DO NOT assert yourself at the expense of those who complain about life. All these tips are correct, but, unfortunately, as practice shows, they work after we discover and change the mechanisms of personal protection, remove energy blocks, expose negative scenarios and destructive schemes, add resources.

The website of S. Karpman notes the following: to get out of the dramatic triangle, you need to find out the reasons for the game. For this, you need to immerse yourself more deeply in yourself, in the inner world of another person and show compassion, accept the unrecognized positive and negative feelings of the Victim. The outer triangle shows scenarios for social roles. The internal one shows how a person decides to act in a certain way. The exploration of the Victim's position reveals the feelings of the Child in scenes of the family scenario. Analysis of the Rescuer's position shows how people interpret the world and discovers how they defend themselves (c) Kohut Oleksandra

DOI (article): https://doi.org/10.32626/2227-6246.2021-51.54-75 
in situations of stress. We find limiting prohibitions in the Persecutor. The drama turns into a triangle of Empathy.

S. Karpman pays special attention to the study of the communicative behaviour of the roles involved in the triangle. According to the scientist I. A. Sterlin, communicative behaviour includes certain rules and traditions of communication of one or another linguocultural community (Sterlin, 23). Karpman, as a representative of the English-speaking culture, notes that active verbs are more attractive to children because they like movement. They often identify themselves with the Persecutor because their role seems more attractive to them than the role of Victims, who use passive verbs to reflect their indecision. In the communication messages of the Victim, one can hear the manifestation of irresponsibility for their own actions: «The pencil has broken», which must be changed to «I have broken the pencil».

To analyse the situation of a personality's personal drama, psychotherapists analyse the script Matrix using fairy tales. They reveal prohibitions on the part of the Persecutor: «Do not think», "Do not notice», "Do not pay attention to the ending», "Do it over and over again». Psychologists Goulding (1997) found 12 themes of early negative decisions: don't live, don't be yourself, don't be a child, don't grow up (stay little), don't make progress, don't do (don't do anything), don't be the first (don't be a leader, don't stand out), don't belong to anyone, don't be close, don't feel good (don't be healthy), don't think, don't feel (Goulding, 1997). The tale reveals the family myth about the Child. Scripted victims lose control of their own impulses and unmet needs, take solace in food, gambling, sex, power, spending money, drug addiction. The tension that grows from underestimating the Victim is transformed into the violence of the Persecutor, who then repents, promises change, and this cycle repeats.

In the unfavourable psychological climate of the group, the Victim serves as a «scapegoat», the Rescuer serves as a «light-

(C) Kohut Oleksandra

DOI (article): https://doi.org/10.32626/2227-6246.2021-51.54-75 
DOI: https://doi.org/10.32626/2227-6246.2021-51 2021. випУСК 51

ning rod» for angry individuals, the Persecutor complicates the game. The latter may covertly protect others by fearing the unfair consequences of past experiences. Such games are supported by communication drivers. The victims believe in salvation: «I will get approval from others if I am perfect, strong, diligent and pleasing". They need to change the language context: "I must be obedient» to "I have the right to love, showing both turbulent and balanced emotions»; "I have to be inconspicuous and comfortable» to "I have the right to stand out from others» and so on. To change them, you can apply cognitive-behavioural psychotherapy, which was started by A. Ellis and A. Beck. The conceptual model of cognitivebehavioural psychotherapy is represented by three aspects: A (activating event) - an event in a person's life is a stimulus for it; B (belief) - the cognitive structure of a person's perception of an event is reflected in the form of thoughts, representations, the individual's personal belief system; C (emotional consequences) - emotional and behavioural consequences.

The inconsistency of the motives and roles of the dramatic triangle causes an internal conflict of the personality, distorts the realistic perception of informational reality. Festinger, the founder of the theory of cognitive dissonance, noted that each person strives for inner harmony (Festinger, 2018). Their views and attitudes tend to unite into groups characterized by the coherence of elements. The existence of dissonance motivates a person to search for balance, integrity, according to K. Jung.

Modern researcher S. Sardarzade noted that in cognitive psychology there are linguistic schemes for understanding a message. These patterns are formed early in life, continue to evolve, and then overlap with later life experiences. They are necessary to maintain a stable view of yourself and the world. People live according to schemes only when external events provoke them. Patients view schemes as a priori truths, which complicates the psychotherapeutic process.

(C) Kohut Oleksandra

DOI (article): https://doi.org/10.32626/2227-6246.2021-51.54-75 
Jeffrey Young identified five domains and 18 maladaptive patterns of perception of reality by the Victim. The schemes are composed of memories, emotions, cognitions, bodily sensations. Early maladaptive schemes: safety acceptance and understanding / breakdown of contact and rejection; need for autonomy, competence and a sense of identity / violation of autonomy; the need for freedom of expression of emotions / focus on others; the need for spontaneity and play / over-caution and inhibitions; need for realistic constraints and self-control / boundary violation. Victims with the domain «Broken ties and rejection» revealed the following maladaptive schemes: rejection / instability, distrust / expectation of tough behaviour, emotional deprivation, defectiveness, social alienation. Victims with the "Autonomy Violation" domain were found to have: addiction / helplessness, vulnerability to harm or disease, confusion / undeveloped identity, academic failure. Victims with the "Violated Boundaries» domain: privilege / grandeur, lack of self-control. For Victims with the «Focus on Others» domain (conditional acceptance of children, if they meet the parents' expectations): obedience, self-sacrifice, seeking approval. Victims with the "Overvigilance and Inhibitions» domain: negativism / pessimism, suppression of emotions, strict standards / pickiness, punishment. The schemes form the victims' complex, which determines their susceptibility to stressful traumatization.

The styles of upbringing of the Victim were distinguished in 2005 at the University of Sheffield in the UK according to the above maladaptive schemes: pessimistic-coward, conditionally-narcissistic, emotionally repulsive, overprotective, humiliating, controlling, ordering, perfectionist, emotionally suppressive upbringing. The narcissistic victim has the following characteristics: irresponsibility, self-deprecation, martyrdom, sadistic tendencies, insatiable thirst for love, low self-esteem, anxiety, compensatory arrogance, fear of failure, fear of success, the need to be always right, difficulty making decisions, 
DOI: https://doi.org/10.32626/2227-6246.2021-51 2021. випУСК 51

alienation from one's own feelings, need in continuous selfadmiration, fear of closeness, fear of being abandoned, torn off, dependence on the opinions of others, apathy, lack of initiative.

The Martyr Victim Complex is the belief that I am the victim and everyone is to blame for this except me. Victims demonstrate their unhappiness and mancipation in various situations, experiencing anger, shame, fear, anxiety, sadness, guilt, resentment. They use blackmail: «If I'm unhappy enough, he will change». Victims seek allies in their misfortunes. Therefore, empathic listening is not enough here, the therapist may be trapped by the client, playing along with him.

Only an adult can cope with extreme and stressful situations. It is possible to recode negative defences thanks to the psychotherapy of neurolinguistic reprogramming of the four codes of the personality's subconscious, as described by the modern psychologist S.V. Kovalyov (Kovalyov, 2016). The neurological code reflects the sensations that the human body possesses: I see, hear, feel, anticipate, smell. The psychosemantic code reveals the psychological meanings of concepts in terms of value and meaning for a particular person. The spatial code is described in their work with projections and dispositions of personality projections in space by B. Helinger. In the most difficult situations, where logic is often powerless, a character code is used.

The author's method "Way out of S. Karpman's triangle» includes all the above studies of famous scientists and has the following successive stages:

- the participant lays out on the floor four sheets of paper with the words: Victim, Persecutor, Rescuer, Observer;

- then the psychologist invites the patient to stand on a piece of paper with the inscription Victim and describe his bodily sensations, emotions, reveal their meaning for himself, find the belief that stands behind these emerging memories; (C) Kohut Oleksandra

DOI (article): https://doi.org/10.32626/2227-6246.2021-51.54-75 
the psychologist observes the patient and provides him with information about those changes that are taking place in him, which he does not notice, because they manifest themselves subconsciously (the above script prescriptions, a feeling of discomfort, negative images of the past) gradually brings him to the self-awareness of the repressed;

- then the psychologist invites the patient to stand on a piece of paper with the inscription Persecutor and perform the same procedure for describing the unconscious, which manifests itself in emotions, feelings, beliefs and leads to the patient's awareness of himself in this role; the psychologist has the opportunity to identify and change the script prohibitions of the Parents;

- then the psychologist invites the patient to stand on a piece of paper with the inscription Rescuer and asks to repeat the procedure; the patient is aware of himself as a Rescuer, recalls some events from the past; at this stage, it is important to answer the question: "What advice can you give to the victim?»; when information has acquired a level of awareness of previous roles, the patient has the resource to change the undesirable state of events; the psychologist can offer him various options for successful coping behaviour, if the patient himself cannot create them;

- then the psychologist invites the patient to stand on a piece of paper with the inscription Observer and go through the same procedure; as a rule, people are comfortable in this state; the psychologist tells them that they have the right to take such a position until they gain awareness and intelligibility in the situation;

- then the psychologist asks to repeat the movement in a circle, stand on each of the sheets, repeating the procedure; as a rule, new insights come to patients, but they no longer has past manifestations; the patients achieve internal integration.

(C) Kohut Oleksandra

DOI (article): https://doi.org/10.32626/2227-6246.2021-51.54-75 


\section{Conclusions}

The state of the victim is considered by the author as the role of a neurotic personality from S. Karpman's dramatic triangle. The Victim has signs of increased anxiety, specific negative defences, suspicion, does not distinguish sincerity from insincerity, is rigid, constantly suffers, does not have emotionally warm relationships, is in an internal conflict, imbalance, in a distortion of the structure of character, inconsistency in actions, inconsistency in behaviour, obsessions. The inner conflict of the Victim is unconscious, and in order to manifest and transform it, it is necessary to apply psychotherapy. In stressful situations, inappropriate reactions of the Victim lead to a violation of psychological defence. Frustration, along with conflict, prompts a person to master new ways of stress reduction, possibly through mechanisms such as identification and substitution. By identifying with the aggressive father, the Child learns the Persecutor's scripts or becomes the Victim.

Conclusions about the effectiveness of the method «Way out of S. Karpman's triangle» was created on the basis of practical experience and empirical diagnostics. Monitoring the condition of patients in the process of applying the new method, the results of testing the level of stress resistance before its use and a month after the practice, the use of a projective method for identifying protective mechanisms, clinical conversation with patients provided an opportunity to state the following: the patient achieved the integration of all the roles of the triangle, the level of self-awareness increased, the repertoire of actions in stressful situations has expanded, the negative programs of the Victim have changed to successful strategies for coping with stress, the role of the Victim has been changed to the state of the Observer, who can think reflectively, and the Rescuer, who can effectively carry out selfhelp in stress. The application of the four codes of the unconscious reveals destructive schemes and script prescriptions for dramatic play and at the same time serves as an indicator (c) Kohut Oleksandra

DOI (article): https://doi.org/10.32626/2227-6246.2021-51.54-75 
for further psychotherapeutic work. Repeated psycho-practice no longer manifests the repressed coded drama programs. The projective technique "Man in the Rain" shows the elements of security; M. Luscher colour test - absence of internal conflict and anxiety; the subjects demonstrate the Adult's position in stress. More than 100 participants of the author's training on the development of personality stress resistance passed the approbation of the new method.

The prospect for further research is to investigate the techniques for transforming the values of a person experiencing a biographical life crisis or stress.

\section{Literature}

Баксанский О. Е., Кучер Е. Н. Когнитивный образ мира. Москва : РООИ «Реабилитация», 2010. 224.

Берн Э. Игры, в которые играют люди. Психология человеческих взаимоотношений. Люди, которые играют в игры. Психология человеческой судьбы. Минск : ПРАМБЕР, 1992. 384 с.

Гулдинг М., Гулдинг Р. Психотерапия нового решения. Теория и практика. Москва : Независимая фирма «Класс», 1997. 288 с.

Дьяков С. Семантична репрезентація соціально-рольової ідентифікації в суб’єктній самоорганізації особистості. Психолінгвістика. Психолингвистика. Psycholinguistics: Зб. наук. праць ДВНЗ «Переяслав-Хлельницький пед. ун-т ілені Григорія Сковороди». Переяслав-Хмельницький : ФОП Домбровська Я. М., 2020. Вип. 27 (1). C. 52-79. URL : https://doi.org/10.31470/2309-1797-2020-27-152-79.

Карпман С. Жћизнь, свободная от игр. Санкт-Петербург : Метанойя, 2016. 342 c.

Ковалев С. В. НЛП: программа «Счастливая судьба». Ставим, запускаем, используем! Москва : Издательство «АСТ», 2016. 416 с.

Когут О. О. Психологія стресостійкості особистості: монографія. Кривий Ріг : ДЮІ МВС України, 2021. 435 с.

Лазарус Р. Теория стресса и психофизиологические исследования. Эмоциональный стресс: физиологические и психологические реакции / под ред. Л. Леви, В. Н. Мясищева. Ленинград, 1970. С. $127-208$.

Малкина-Пых И. Виктимология. Психология поведения жертвы. Санкт-Петербург : Издательство «Питер», 2016. 832 с.

(C) Kohut Oleksandra

DOI (article): https://doi.org/10.32626/2227-6246.2021-51.54-75 
DOI: https://doi.org/10.32626/2227-6246.2021-51 2021. випуск 51

Моісеєв Є. М., Джужа О. М., Василевич В. В. та ін. Кримінологічна віктимологія / за заг. ред. професора О. М. Джужі. Київ : Київський національний ун-т внутрішніх справ, 2006. 416 с.

Наугольник Л. Б. Психологія стресу. Львів : Львівський державний університет внутрішніх справ, 2015. 324 с.

Одинцова М. Психология жертвы. Сказкотерапия для жертвы. Самара : Бахрах-M, 2010. 240 с.

Ривман Д. В. Криминальная виктимология. Санкт-Петербург : Питер, 2002. 304 c.

Сардарзаде С. Взаємодія когнітивних та емоційних схем у осіб з тривожними, депресивними та спричиненими стресом розладами: дис. ... канд. психол. наук: спец. 19.00.04 «Медична психологія». Київ : Інститут психології імені Г. С. Костюка НАПН України, 2019. 201 c.

Селье Г. Стресс без дистресса. Рига : Виеда, 1992. 109 с.

Фестингер Л. Теория когнитивного диссонанса. Москва : Эксмо, 2018. 256 c.

Хеллингер Б. Порядок помощи. Москва : Институт консультирования и системных решений, 2013. 224 с.

Хорни К. Невроз и личностный рост: борьба за самореализацию. Санкт-Петербург : ПИТЕР, 2019. 520 с.

Христенко В. Е. Психология поведения жертвы. Ростов-на-Дону : Феникс, 2004. 416 с.

Юнг К. Г. Сознание и бессознательное: сборник / пер. с англ. Санкт-Петербург : Университетская книга, 1997. 544 с.

Язык и культура: взгляд молодых исследователей: сборник статей студентов и магистрантов факультета прикладной лингвистики. Иркутск : Изд. ИрГТУ, 2014. С. 9-10.

Aaron, T. Beck (1991). Cognitive Therapy and the Emotional Disorders. Penguin. $255 \mathrm{p}$.

Dollard, J., Miller, Neal E., Doob, Leonard W., Mowrer, Orval H., \& Sears, Robert R. (1939). Frustration and Aggression. New Haven, CT, US : Yale University Press.

Yang, D. (2003). Schema Therapy: A Practitioner's Guide. Publishing house : The Guilford Press. 436 p.

\section{References}

Baksanskii, O. E., \& Kucher, E. N. (2010). Kognitivnyi obraz mira [Cognitive image of the world]. Moskva : ROOI «Reabilitatsiia» [in Russian].

Bern, E. (1992). Igry, $v$ kotoryie igraiut liudi. Psikhologiia chelovecheskikh vzaimootnoshenii. Liudi, kotoryie igraiut $v$ igry. Psikhologiia chelo-

(C) Kohut Oleksandra

DOI (article): https://doi.org/10.32626/2227-6246.2021-51.54-75 
vecheskoi sudby [Games that people play. Psychology of human relationships. People who play games. Psychology of human destiny]. Minsk : PRAMBER [in Russian].

Gulding, M., \& Gulding, R. (1997). Psikhoterapiia novogo resheniia: Teoriia i praktika [Psychotherapy of a new solution: Theory and practice]. Moskva : Nezavisimaia firma "Klass» [in Russian].

Diakov, S. (2020). Semantychna reprezentatsiia sotsialno-roliovoi identyfikatsii v subiektnii samoorganizatsii osobystosti [Semantic representation of socio-role identification in the subjective self-organization of the individual]. Psykholinhvistyka. Psikholingvistika. Psycholinguistics: Zb. nauk. prats DVNZ «Pereiaslav-Khmelnytskyi ped. un-t imeni Hryhoriia Skovorody» - Psycholinguistics. Psycholinguistics. Psycholinguistics: Collection of Scientific Papers of PereiaslavKhmelnytskyi Hryhorii Skovoroda Pedagogical University, 27 (1), 52-79. Pereiaslav-Khmelnytskyi : FOP Dombrovska Ya. M. Retrieved from https://doi.org/10.31470/2309-1797-2020-27-1-52-79 [in Ukrainian].

Karpman, S. (2016). Zhizn, svobodnaia ot igr [Life free from games]. Sankt-Peterburg : Metanoia [in Russian].

Kovalev, S. V. (2016). NLP: programma «Schastlivaia sudba». Stavim, zapuskaiem, ispolzuiem! [NLP: Happy Fate program. Put, run, use!]. Moskva : AST [in Russian].

Kohut, O. O. (2021). Psykholohiia stresostiikosti osobystosti [Psychology of personality stress]. Kryvyi Rih : DYuI MVS Ukrainy [in Ukrainian].

Lazarus, R. (1970). Teoriia stressa i psikhofiziologicheskiie issledovaniia. Emotsionalnyi stress: fiziologicheskiie i psikhologicheskiie reaktsii [Stress theory and psychophysiological research. Emotional stress: physiological and psychological reactions]. L. Levi, B. H. Myasishcheva (Eds.). (pp. 127-208). Leningrad [in Russian].

Malkina-Pykh, I. (2016). Viktimologiia. Psikhologiia povedeniia zhertvy. [Victimology. Psychology of victim behavior]. Sankt-Peterburg : Izdatelstvo «Piter» [in Russian].

Moiseiev, Ye. M., Dzhuzha, O. M., Vasylevych, V. V., at al. (2006). Kryminolohichna viktymolohiia [Criminological Victimology]. Kyiv : Kyiv. nats. un-t vnutr. sprav [in Ukrainian].

Nauholnyk, L. B. (2015). Psykholohiia stresu [Psychology of stress]. Lviv : Lvivskyi derzhavnyi universytet vnutrishnikh sprav [in Ukrainian].

Odintsova, M. (2015). Psikhologiia zhertvy. Skazkoterapiia dlia zhertvy [Psychology of victim. Fairy tale therapy for the victim]. Samara : Bakhrakh-M [in Russian].

(C) Kohut Oleksandra

DOI (article): https://doi.org/10.32626/2227-6246.2021-51.54-75 
DOI: https://doi.org/10.32626/2227-6246.2021-51 2021. випУСК 51

Rivman, D. V. (2002). Kriminalnaia viktimologiia [Criminal victimology]. Sankt-Peterburg : Piter [in Russian].

Sardarzade, S. (2019). Vzaiemodiia kohnityvnykh ta emotsiinykh skhem u osib z tryvozhnymy, depresyvnymy ta sprychynenymy stresom rozladamy [Interaction of cognitive and emotional patterns in people with anxiety, depression and stress-induced disorders]. Extended abstract of candidate's thesis. Kyiv : Instytut psykholohii imeni G. S. Kostiuka NAPN Ukrainy [in Ukrainian].

Sele, G. (1992). Stress bez distressa [Stress without distress]. Riga : Vieda [in Russian].

Festinger, L. (2018). Teoriia kognitivnogo dissonansa [Cognitive dissonance theory]. Moskva : Eksmo [in Russian].

Hellinger, B. (2013). Poriadok pomoshchi [The order of help]. Moskva : Institut konsultirovaniia i sistemnykh reshenii [in Russian].

Khorni, K. (2019). Nevroz i lichnostnyi rost: borba za samorealizatsiiu [Neurosis and personal growth: the struggle for self-realization]. Sankt-Peterburg : Piter [in Russian].

Khristenko, V. E. (2004). Psikhologiia povedeniia zhertvy [Psychology of victim behavior]. Rostov-na-Donu : Feniks [in Russian].

Yung, K. G. (1997). Soznaniie i bessoznatelnoie [Consciousness and unconscious ]. Sankt-Peterburg : Universitetskaia kniga [in Russian].

Yazyk i kultura: vzgliad molodykh issledovatelei: sbornik statei studentov $i$ magistrantov fakulteta prikladnoi lingvistiki [Language and culture: the view of young researchers: a collection of articles by students and undergraduates of the Faculty of Applied Linguistics]. (2014). (pp. 9-10). Irkutsk : Izd. IrGTU [in Russian].

Aaron, T. Beck. (1991). Cognitive Therapy and the Emotional Disorders. Penguin.

Dollard, J., Miller, N. E., Doob, L. W., Mowrer, O. H., \& Sears, R. R. (1939). Frustration and Aggression. New Haven, CT, US : Yale University Press.

Yang, D. (2003). Schema Therapy: A Practitioner's Guide. Publishing house : The Guilford Press.

Когут Олександра. Зміна негативного захисту особистості на успішні стратегії опанування стресом у психолінгвістичному аспекті

\section{АНОТАЦІЯ}

Mета cmammi. На основі теоретичного аналізу когнітивних схем, сценарних матриць деструктивних ігор та їх трансакцій автором зроблено (c) Kohut Oleksandra

DOI (article): https://doi.org/10.32626/2227-6246.2021-51.54-75 
DOI: https://doi.org/10.32626/2227-6246.2021-51 2021. випуск 51

спробу застосувати власний психотерапевтичний метод "Вихід із трикутника С. Карпмана».

Методи та методики дослідження. Застосовано теоретичний аналіз психотерапевтичних напрямів роботи з проблемою Жертви в психологічній научі. Приділено увагу причинам стресової проблеми, зокрема, звичним способам реакції людини на стрес: схемам, сценаріям, сценарним приписам, сценарним матрицям. Досліджено емпіричні показники ефективності застосування нових методів, серед яких: проєктивна методика О. С. Романової та Т. І. Ситько "Людина під дощем»; діагностика стресу за кольоровими картками Макса Люшера; авторська методика "Діагностика стресостійкості особистості»; метод "Трансактного аналізу» Є. П. Ільїна; метод клінічної бесіди.

Результати дослідження. Більшість осіб, які мають потребу в розвитку стресостійкості, на початкових етапах актуалізують проблему співзалежних стосунків з агресорами або жертвами й застосовують негативні захисти, що загалом сприяє неадекватним реакціям у стресі. Звільнення від внутрішніх причин залежності, від деструктивних захистів і схем, перехід у стан добровільного спостерігача надають людині можливість самій обирати способи реакцій у стресі, копінг-стратегії, життєві сиенарії, планувати майбутнє, жити власним життям. Авторкою здійснено теоретичний аналіз психолінгвістичного аспекту розвитку особистості. Зокрема, досліджено комунікативну поведінку особистості: комунікативно-когнітивні схеми, трансактні сценарні приписи та драйвери. Особливу увагу в дослідженні приділено таким психотерапевтичним напрямам, як психоаналітичний, гештальт-напрям, когнітивно-поведінковий, нейролінгвістичне інтегроване програмування. Вони надали змогу розкрити сутність і зміст психолінгвістичних повідомлень Жертви, Переслідувача та Рятівника.

Висновки. Про ефективність застосування методу "Вихід із трикутника С. Карпмана» свідчать результати емпіричної діагностики. Спостереження та бесіда надали підстави констатувати таке: пацієнти досягли інтеграції всіх ролей трикутника, рівень самосвідомості розширився, відбулася зміна негативних програм на успішні стратегії опанування стресом, роль Жертви змінено на успішні стратегії опанування стресом. Проективна методика "Людина під дощем» виявила елементи захищеності та відсутність тривожних станів; кольоровий тест М. Люшера - відсутність внутрішнього конфрлікту та наявність

(C) Kohut Oleksandra

DOI (article): https://doi.org/10.32626/2227-6246.2021-51.54-75 
DOI: https://doi.org/10.32626/2227-6246.2021-51 2021. виПуСК 51

здорових станів. Апробацію нового методу пройшло понад 100 учасників тренінгу з розвитку стресостійкості особистості.

Ключові слова: механізми захисту, трикутник С. Карпмана, стан Жертви, стан Переслідувача, стан Рятівника, стан Спостерігача, успішні копінг-стратегії, когнітивна психотерапія.

\section{Когут Александра. Изменение негативной защиты личности на успеш- ные стратегии овладения стрессом в психолингвистическом аспекте}

\section{АННОТАЦИЯ}

Цель статьи. На основе теоретического анализа когнитивных схем, сценарных матриц деструктивных игр и их трансакций автором сделана попытка применить собственный психотерапевтический метод «Выход из треугольника С. Карпмана».

Методы и методики исследования. Применен теоретический анализ психотерапевтических направлений работы с проблемой Жертвы в психологической науке. Уделено внимание причинам стрессовой проблемы, в частности, привычным способам реакции человека на стресс: схемам, сценариям, сценарным предписаниям, сценарным матрицам. Исследованы эмпирические показатели эфррективности применения новых методов, среди которых: проективная методика А. С. Романовой и Т. И. Ситько "Человек под дождем»; диагностика стресса за цветными карточками Макса Люшера; авторская методика "Диагностика стрессоустойчивости личности»; метод «трансактного анализа» Е. П. Ильина; метод клинической беседы.

Результаты исследования. Большинство лии, нуждающихся в развитии стрессоустойчивости, на начальных этапах актуализируют проблему созависимых отношений с агрессорами или жертвами и применяют негативные защиты, что в целом способствует неадекватным реакциям в стрессе. Освобождение от внутренних причин зависимости, от деструктивных защит и схем, переход в состояние добровольного наблюдателя позволяют человеку самому выбирать способы реакций в стрессе, копинг-стратегии, жизненные сценарии, планировать будущее, жить своей жизнью. Автором осуществлен теоретический анализ психолингвистических аспектов развития личности. В частности, исследовано коммуникативное поведение личности: коммуникативно-когнитивные схемы, трансактные сценарные предписания и драйверы. (c) Kohut Oleksandra

DOI (article): https://doi.org/10.32626/2227-6246.2021-51.54-75 
DOI: https://doi.org/10.32626/2227-6246.2021-51 2021. ВИПУСК 51

Особое внимание в исследовании уделено таким психотерапевтическим направлениям, как психоаналитический, гештальт-направление, когнитивно-поведенческий, нейролингвистическое интегрированное программирование. Они предоставили возможность раскрыть сущность и содержание психолингвистических сообщений Жертвы, Преследователя и Спасителя.

Выводы. Об эфрфективности применения метода "Выход из треугольника С. Карпмана» свидетельствуют результаты эмпирической диагностики. Наблюдения и беседа предоставили основания констатировать следующее: пациенты достигли интеграции всех ролей треугольника, уровень самосознания расширился, произошла смена негативных программ на успешные стратегии освоения стрессом, роль Жертвы изменена на успешные стратегии освоения стрессом. Проективная методика "Человек под дождем» обнаружила элементы защищенности и отсутствие тревожных состояний; иветной тест М. Люшера - отсутствие внутреннего конфликта и наличие здоровых состояний. Апробацию нового метода прошли более 100 участников тренинга по развитию стрессоустойчивости личности.

Ключевые слова: механизмы защиты, треугольник С. Карпмана, состояние Жертвы, состояние Преследователя, состояние Спасителя, состояние Наблюдателя, успешные копинг-стратегии, когнитивная психотерапия.

Original manuscript received January 09, 2021 Revised manuscript accepted February 13, 2021

(C) Kohut Oleksandra

DOI (article): https://doi.org/10.32626/2227-6246.2021-51.54-75 